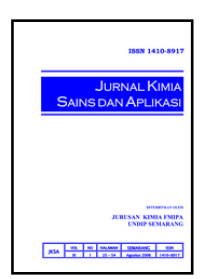

\title{
Sintesis dan Karakterisasi Porous Carbon dari Sukrosa Menggunakan Asam Sulfat dan Asam Nitrat
}

\author{
Istiqomah $^{\mathrm{a}}$, Pardoyo $^{\mathrm{a}}$, Taslimah ${ }^{\mathrm{a}}$ \\ a Inorganic Chemistry Laboratory, Chemistry Department, Faculty of Sciences and Mathematics, Diponegoro University, Jalan Prof. \\ Soedarto, Tembalang, Semarang \\ * Corresponding author: taslimah@live.undip.ac.id
}

\section{Article Info}

Keywords:

Porous carbon, sucrose,

carbonization, used

frying oil.

\section{Abstract}

Porous carbon is a versatile material because it has a large surface area and high porosity. porous carbon can be made from various substances that have the composition of hydrocarbons such as carbohydrates, wood sticks or substances containing other hydrocarbon compounds with high temperature heating and activation process. This study aims were to obtain porous carbon from sucrose and to determine the characteristics of the products obtained. The synthesis product was analyzed using FTIR, $\mathrm{X}$-Ray diffraction and surface area analyzer. porous carbon obtained from the use of nitric acid increased its surface area and pore volume by $24 \%$ and $25 \%$ respectively relative to porous carbon made by using sulfuric acid. By presence of calcination treatment, porous carbon made with sulfuric acid also increased its surface area and pore volume by $97 \%$ and $98 \%$ respectively. The porous carbon obtained could be used as adsorbent of used cooking oil. porous carbon made using nitric acid had the power of bleaching of residual oils higher than other porous carbon.
Kata kunci:

Porous carbon, sukrosa,karbonasi, Minyak goreng bekas

\begin{abstract}
Abstrak
Porous carbon merupakan suatu material serbaguna karena mempunyai luas permukaan yang besar dan porositas yang tinggi. porous carbon dapat dibuat dari berbagai zat yang memiliki susunan senyawa hidrokarbon seperti karbohidrat, batang kayu atau zat yang mengandung senyawa hidrokarbon lainnya dengan pemanasan temperatur tinggi serta proses aktivasi. Penelitian ini bertujuan untuk memperoleh porous carbon dari sukrosa serta menentukan karakteristik produk yang diperoleh. Produk sintesis dianalisis menggunakan spektrofotometer FTIR, X-Ray diffraction dan surface area analyzer. porous carbon yang diperoleh dari penggunaan asam nitrat meningkat luas permukaan dan volume pori berturut-turut sebesar $24 \%$ dan $25 \%$ relatif terhadap porous carbon yang dibuat dengan menggunakan asam sulfat. Adanya perlakuan kalsinasi, porous carbon yang dibuat dengan asam sulfat juga meningkatkan luas permukaan dan volume pori berturut-turut sebesar $97 \%$ dan $98 \%$. porous carbon yang diperoleh dapat digunakan sebagai adsorben minyak goreng sisa pakai. porous carbon yang dibuat menggunakan asam nitrat mempunyai daya pemucatan terhadap minyak sisa pakai yang lebih tinggi daripada porous carbon yang lain.
\end{abstract}

\section{Pendahuluan}

Porous carbon merupakan suatu material berpori yang tersusun oleh ikatan kovalen karbon, mempunyai luas permukaan besar dan porositas yang tinggi. porous carbon mempunyai banyak kegunaan diantaranya dapat diaplikasikan sebagai filter, membran, adsorben, elektroda dan catalyst support [1].

Bruno dkk. [2], telah melakukan sintesis porous carbon dari sukrosa serta menambahkan TEOS (tetraetil ortosilikat) sebagai template menggunakan reagen $\mathrm{HCl}$, 
kemudian dikalsinasi pada suhu $900^{\circ} \mathrm{C}$. Produk yang diperoleh adalah material berukuran mesopori yaitu 20 nm-30 nm. porous carbon juga dapat disintesis menggunakan beberapa metode diantaranya dengan menggunakan sistem polimerisasi resorsenol/formaldehida (RF) dari larutan yang mengandung resorsenol, formaldehida dan surfaktan menggunakan suhu tinggi di atas $900^{\circ} \mathrm{C}$ dengan luas permukaan sebesar $671 \mathrm{~m}^{2} / \mathrm{g}$.

Dalam penelitian ini, proses pembuatan porous carbon disintesis dari bahan karbohidrat yang berupa sukrosa sebagai sumber karbon dan natrium silikat sebagai silica template (cetakan) yang dapat memberikan kontribusi dalam meningkatkan luas permukaan porous carbon yang dihasilkan. Selain itu juga digunakan asam sulfat dan asam nitrat sebagai senyawa pendehidrasi sukrosa serta sebagai senyawa yang mengubah larutan natrium silikat menjadi silika gel (silica template). Proses sintesis porous carbon dilakukan dengan melarutkan sukrosa dengan $\mathrm{H}_{2} \mathrm{O}$. Pelarutan dengan $\mathrm{H}_{2} \mathrm{O}$ dengan adanya sedikit asam akan membuat senyawa sukrosa terhidrolisis dan menyebabkan ikatan glukosida terputus menghasilkan glukosa dan fruktosa seperti yang ditunjukkan pada gambar 1 .
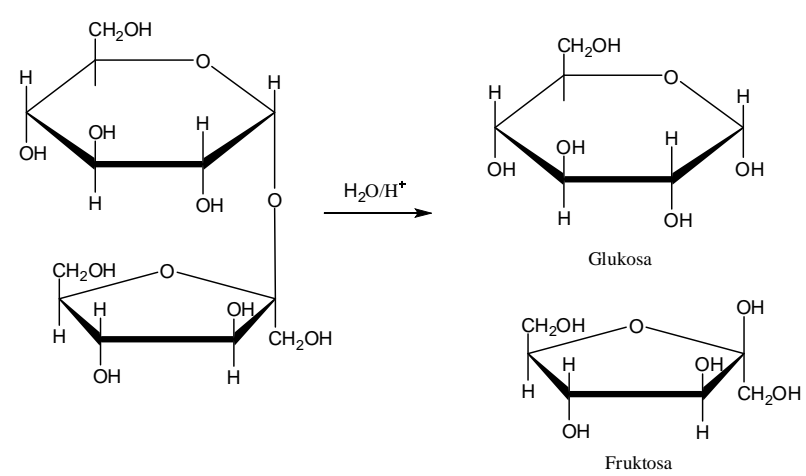

Gambar 1. Hidrolisis Sukrosa

Asam sulfat dan asam nitrat keduanya bersifat sebagai oksidator, namun kemampuan oksidasinya berbeda. Penggunaan jenis asam yang berbeda pada proses karbonasi diharapkan produk yang diperoleh mempunyai sifat atau karakter yang berbeda. Karakterisasi produk dilakukan dengan menggunakan spektrofotometer FTIR, X-Ray diffraction dan surface area analyzer serta dilakukan uji adsorpsi terhadap minyak goreng sisa pakai.

Penelitian ini bertujuan untuk memperoleh porous carbon dari sukrosa, dengan menggunakan asam sulfat dan asam nitrat. Menentukan karakteristik dari produk yang telah diperoleh serta mengaplikasikan porous carbon sebagai adsorben dalam proses pemucatan minyak goreng sisa pakai. Pengujian porous carbon hasil sintesis tersebut sebagai adsorben pada dasarnya bertujuan untuk menentukan kemampuan pemucatan porous carbon yang dihasilkan terhadap minyak goreng sisa pakai. Pemucatan minyak sisa pakai dilakukan dengan cara adsorpsi dengan adsorben porous carbon yang dihasilkan.

\section{Metodologi}

Sintesis porous carbon dari Sukrosa dengan Penambahan Natrium Silikat

Sukrosa dilarutkan dalam aquades kemudian ditambahkan dengan natrium silikat, kemudian ditambahkan asam sulfat. Hasilnya kemudian dikeringkan, dicuci larutan $\mathrm{HF}$ ( $5 \%$; distirer kembali selama 10 menit, dicuci menggunakan aquades hingga mendekati netral, kemudian dikalsinasi. porous carbon yang dihasilkan kemudian digunakan sebagai agen pemucat (bleaching agent) minyak goreng sisa pakai. Karakterisasi produk dilakukan dengan menggunakan Fourier Transform Infra Red (FTIR) untuk mengetahui gugus apa saja yang terdapat di dalam struktur Porous carbon, difraktometer sinar-X untuk mengetahui kristalinitas dari sampel tersebut dan Brunauer-EmmetTeller (BET) untuk mengetahui luas permukaan dan ukuran pori-pori.

\section{Analisis FTIR, XRD, dan BET}

Analisis FTIR dilakukan untuk mengetahui gugus fungsi yang ada pada porous carbon setelah dilakukan penambahan asam sulfat dan asam nitrat. Analisis XRD dilakukan untuk mengetahui tingkat kekristalan pada porous carbon setelah dilakukan penambahan asam sulfat dan asam nitrat. Analisis BET dilakukan untuk mengetahui luas permukaan pada porous carbon setelah dilakukan penambahan asam sulfat dan asam nitrat.

\section{Pengujian porous carbon Sebagai adsorben pada Pemucatan (Bleaching) Minyak goreng sisa pakai}

Proses bleaching dilakukan dengan menggunakan 10 mL minyak goreng sisa pakai dan $2 \%$ b/v porous carbon dihasilkan. Dari hasil penelitian, didapatkan bahwa penggunaan porous carbon dengan variasi asam dan suhu yang ditambahkan menghasilkan tingkat pemucatan minyak goreng sisa pakai yang berlainan.

\section{Hasil dan Pembahasan}

\section{Sintesis porous carbon dari Sukrosa dengan Menggunakan Silica Template}

Porous carbon yang disintetis dengan asam sulfat tanpa kalsinasi menghasilkan padatan karbon yang berwarna hitam $\left(\mathrm{C}_{1}\right)$, sedangkan yang menggunakan kalsinasi menghasilkan padatan karbon berwarna putih $\left(\mathrm{C}_{2}\right)$. Untuk porous carbon yang menggunakan asam nitrat menghasilkan padatan karbon berwarna putih $\left(C_{3}\right)$. Perbedaan intensitas warna ini disebabkan oleh pengaruh asam dan suhu yang digunakan. Selain warna, tekstur dari ketiga sampel ini juga berbeda untuk $\mathrm{C}_{1}$ teksturnya lebih kasar bentuk partikelnya seperti granul, untuk $\mathrm{C}_{2}$ lebih halus seperti serbuk, sedangkan untuk $\mathrm{C}_{3}$ teksturnya sedikit kasar ukuran partikelnya seperti granul. Perbedaaan warna dan ukuran dari porous carbon ini dapat dilihat pada gambar 2 berikut. 


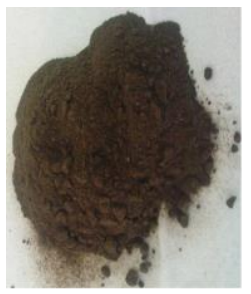

C1

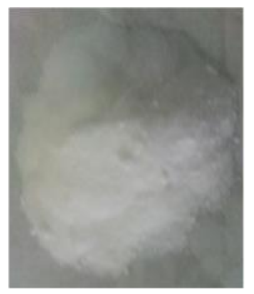

$\mathrm{C} 2$

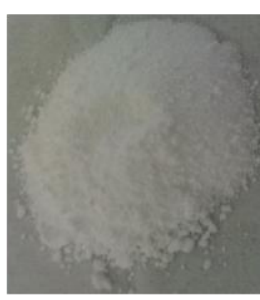

C3
Gambar 2. $C_{1}=$ porous carbon menggunakan asam sulfat tanpa kalsinasi; $\mathrm{C} 2$ = porous carbon menggunakan asam sulfat, kalsinasi pada suhu $600^{\circ} \mathrm{C}$ selama 4 jam dengan pengaliran gas nitrogen; dan $\mathrm{C}_{3}=$ porous carbon menggunakan asam nitrat

Pembuatan porous carbon dengan menambahkan natrium silikat sebagai silica template berlangsung sama seperti sintetis porous carbon sebelumnya, namun pada saat asam sulfat atau asam nitrat ditambahkan, tidak hanya sukrosa yang mengalami reaksi, akan tetapi natrium silikat yang ditambahkan juga akan berubah menjadi silika gel.

Partikel-partikel karbon dan silika gel yang terbentuk lama-kelamaan akan memadat seiring dengan berkurangnya uap air serta lamanya waktu pendiaman. Atom-atom karbon yang tidak stabil akan membentuk ikatan karbon yang baru untuk menuju struktur yang lebih stabil. Silika gel yang terbentuk pada saat hampir bersamaan akan mengisi ruang-ruang bagian-bagian tertentu dengan padatan karbon di sekelilingnya. Karbon kemudian dicuci sampai netral dengan aquades dan dikeringkan selama 2 jam pada temperatur $120^{\circ} \mathrm{C}$. Produk yang dibuat dengan menggunakan asam sulfat sebagian dikalsinasi pada suhu $600^{\circ} \mathrm{C}$ dengan pengaliran gas nitrogen selama 4 jam. Silika gel dapat dihilangkan menggunakan asam fluorida ( $\mathrm{HF} 10 \%$ ) menghasilkan $\mathrm{H}_{2}\left(\mathrm{SiF}_{6}\right)$ yang larut dalam air [3].

$$
\mathrm{SiO}_{2}+6 \mathrm{HF} \rightarrow \mathrm{H}_{2}\left(\mathrm{SiF}_{6}\right)+2 \mathrm{H}_{2} \mathrm{O}
$$

Hasil dari sintesis porous carbon dikarakterisasi dengan menggunakan metode spektrofotometri FTIR. Metode tersebut digunakan untuk mengetahui kemungkinan terjadinya perubahan gugus fungsi dari sukrosa hingga menjadi suatu Porous carbon. Analisis dilakukan terhadap produk porous carbon yang dihasilkan dengan menggunakan asam sulfat dengan kalsinasi dan tanpa kalsinasi, serta dengan menggunakan $\mathrm{HNO}_{3}$ tanpa kalsinasi. Sukrosa memiliki serapan yang khas, yang dapat berasal dari gugus hidroksil, ikatan senyawa karbon dengan karbon (C-C) dan ikatan karbon dengan oksigen (C-O).

Dari spektra tersebut terlihat bahwa masih terdapat pita serapan dari gugus $\mathrm{O}-\mathrm{H}$, yaitu pada bilangan gelombang $3425,58 \mathrm{~cm}^{-1}$ pada sampel $\mathrm{C}_{1} ; \mathrm{C}_{2}$ dan $\mathrm{C}_{3}$. Sampel tersebut masih terdapat pita serapan hidroksil (O-H) yang diperkirakan berasal dari pita serapan gugus hidroksil yang terikat pada gugus silanol ( $\mathrm{Si}-\mathrm{OH}$ ). Namun, tidak dapat dipungkiri bahwa pada sampel tersebut juga terdapat pita serapan $\mathrm{O}-\mathrm{H}$ dari gugus alkohol. Adanya gugus alkohol tersebut menandakan bahwa tidak semua gugus hidroksil $(\mathrm{O}-\mathrm{H})$ hilang terdehidrasi menjadi molekul air. Hal ini dapat terjadi karena pita serapan yang dihasilkan gugus hidroksil yang terikat sebagai alkohol $(\mathrm{C}-\mathrm{OH})$ dan silanol $(\mathrm{Si}-\mathrm{OH})$ berada dalam daerah bilangan gelombang yang saling berdekatan. Pita serapan gugus alkohol berada pada daerah bilangan gelombang $3200-3500 \mathrm{~cm}^{-1}$ sedangkan pita serapan gugus hidroksil pada silanol $(\mathrm{OH}$ yang terikat pada $\mathrm{Si}$ ) berada pada daerah bilangan gelombang $3200-3700 \mathrm{~cm}^{-1}$ [4]. Perkiraan adanya pita serapan dari gugus silanol diperkuat dengan adanya pita serapan siloksan ( $\mathrm{Si}-\mathrm{O}-\mathrm{Si}$ ) yang teridentifikasi pada bilangan gelombang $1087,85 \mathrm{~cm}^{-1}$ pada sampel $\mathrm{C}_{1}$ dan $\mathrm{C}_{2}$, sedangkan pada sampel $\mathrm{C}_{3}$ dapat teridentifikasi pada bilangan gelombang 1095,57 $\mathrm{cm}^{-1}$. Adanya serapan silika gel tersebut diakibatkan kurang sempurnanya penghilangan Si oleh asam flourida dari senyawa porous carbon yang dihasilkan.
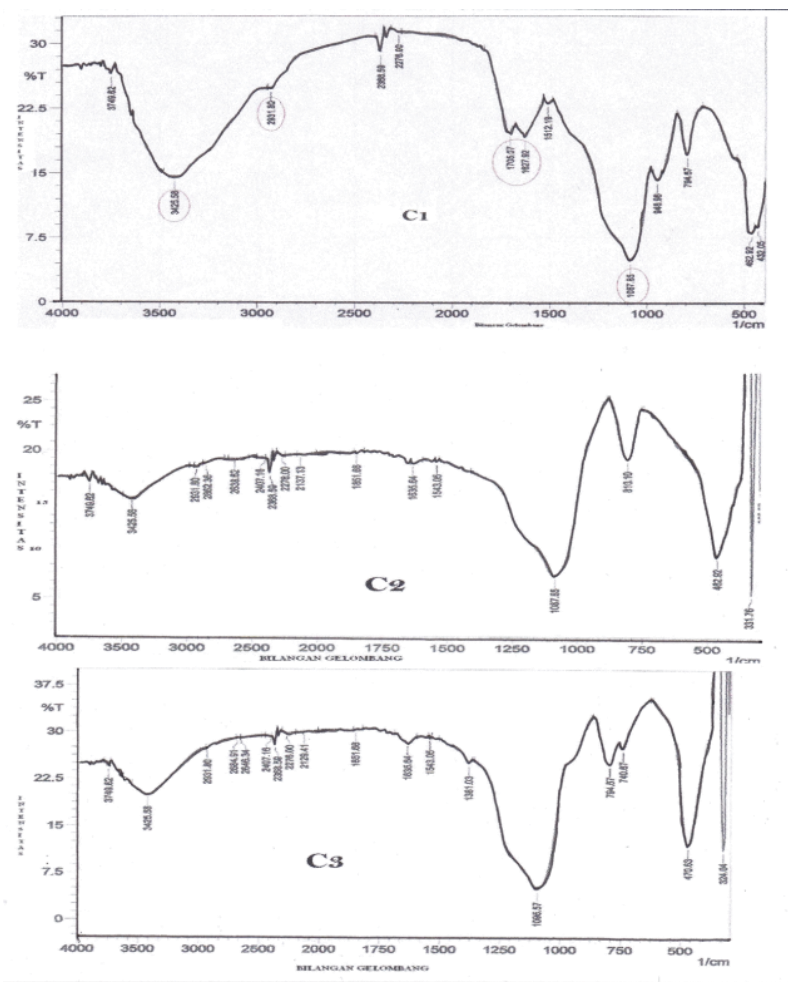

Gambar 3. Spekta FTIR: C1: menggunakan $\mathrm{H}_{2} \mathrm{SO}_{4}$, tanpa kalsinasi ; $\mathrm{C} 2$ :menggunakan $\mathrm{H}_{2} \mathrm{SO}_{4}$, dikalsinasi pada suhu $600^{\circ} \mathrm{C} ; \mathrm{C} 3$ : menggunakan $\mathrm{HNO}_{3}$, tanpa kalsinasi

Spektra di atas juga teridentifikasi adanya pita serapan gugus karboksilat yaitu pada bilangan gelombang yang sama pada ketiga spektra porous carbon (sampel $\mathrm{C}_{1} ; \mathrm{C}_{2}$ dan $\mathrm{C}_{3}$ ) yaitu pada bilangan gelombang $2931,80 \mathrm{~cm}^{-1}$ yang merupakan pita serapan O-H. Serapan pendukung yang menandakan adanya asam karboksilat tersebut dapat diidentifikasi pada bilangan gelombang $1705,07 \mathrm{~cm}^{-1}$ yang menandakan adanya pita serapan dari uluran $\mathrm{C}=\mathrm{O}$ pada sampel $\mathrm{C}_{1}$. Pita serapan pendukung adanya asam karboksilat yang terdapat pada sampel $\mathrm{C}_{1}$ tidak semuanya nampak pada sampel $\mathrm{C}_{2}$ dan $\mathrm{C}_{3}$, hal ini di karenakan pita serapan tersebut tertutupi oleh serapan yang berasal dari silika gel yang lebih kuat. Selain itu dimungkinkan karena pengaruh kalsinasi pada suhu tinggi $600^{\circ} \mathrm{C}$ untuk sampel $\mathrm{C}_{2}$, sedangkan 
pada sampel $\mathrm{C}_{3}$ karena pengaruh asam yang digunakan yaitu asam nitrat.

Adanya asam karboksilat maupun keton diakibatkan karena reaksi oksidasi pada sukrosa oleh asam sulfat dan asam nitrat yang bersifat sebagai oksidator kuat. Asam ini dapat mengoksidasi alkohol primer yang terbentuk pada karbon menjadi aldehida kemudian jika direaksikan lebih lanjut akan menghasilkan asam karboksilat. Sedangkan alkohol sekunder dapat dioksidasi menjadi keton. Adanya senyawa keton tersebut dapat diidentifikasi pada bilangan gelombang $1627,92 \mathrm{~cm}^{-1}$ untuk sampel $\mathrm{C}_{1}$, sedangkan pada sampel $\mathrm{C}_{2}$ dan $\mathrm{C}_{3}$ dapat diidentifikasi pada bilangan gelombang $1635,64 \mathrm{~cm}^{-1}$ yang menandakan adanya pita serapan dari uluran $\mathrm{C}=\mathrm{O}$. Hal ini sesuai dengan literatur yang menyebutkan bahwa gugus karbonil dapat teridentifikasi pada bilangan gelombang $1700-1725 \mathrm{~cm}^{-1}$ untuk senyawa asam karboksilat dan $1660-1750 \mathrm{~cm}^{-1}$ untuk senyawa keton [5].

Pada spektra $\mathrm{C}_{1}, \mathrm{C}_{2}$ dan $\mathrm{C}_{3}$ menunjukan adanya pita serapan $\mathrm{C}-\mathrm{H}$ dari alkena yaitu pada bilangan gelombang $794,87 \mathrm{~cm}^{-1}, 810,10 \mathrm{~cm}^{-1}, 794,87 \mathrm{~cm}^{-1}$. Serapan pendukung adanya pita serapan $\mathrm{C}=\mathrm{C}$ dari gugus alkena yaitu pada bilangan gelombang 1512,19 untuk sampel $\mathrm{C}_{1}$ dan pada bilangan gelombang $1543,05 \mathrm{~cm}^{-1}$ pada sampel $\mathrm{C}_{2}$ dan $\mathrm{C}_{3}$. Pita serapan gugus alkena berada pada daerah bilangan gelombang $1475-1600 \mathrm{~cm}^{-1}(\mathrm{C}=\mathrm{C})$ sedangkan pita serapan $\mathrm{C}-\mathrm{H}$ berada pada daerah bilangan gelombang 690-900 $\mathrm{cm}^{-1}[6]$.

Berdasarkan interpretasi spektra IR tersebut di atas dapat dinyatakan bahwa sampel porous carbon yang diperoleh mempunyai gugus karboksilat, $\mathrm{O}-\mathrm{H}$ alkohol dan alkena. Adanya gugus tersebut pada porous carbon yang diperoleh memiliki kemiripan dengan karbon aktif.

Analisis produk dengan menggunakan difraktometer sinar-X dilakukan untuk menentukan tingkat kristalinitas dari produk yang diperoleh, difraktogram hasil pengukuran disajikan pada Gambar 4 berikut.

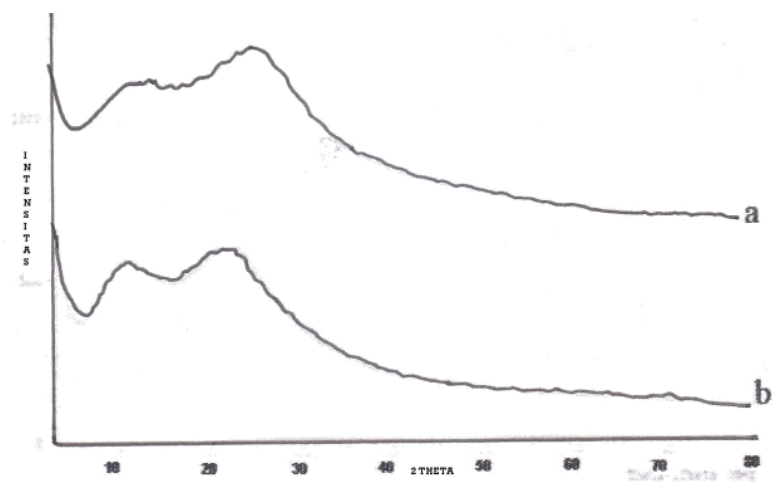

Gambar 4. Difraktogram porous carbon yang dibuat dengan reagen asam sulfat : a. Tanpa kalsinasi ; b. Kalsinasi pada $600^{\circ} \mathrm{C}$

Difraksi sinar-X ini dilakukan menggunakan sumbu $X$-ray dari $\mathrm{Cu} \mathrm{K} \alpha(1,54060 \alpha)$ dengan voltase 40 $\mathrm{kV}$ dan arus $30 \mathrm{~mA}$. Dari hasil difraksi terlihat bahwa kedua difraktogram porous carbon tersebut mempunyai pola difraksi yang sama. Dari kedua pola difraktogram secara umum menampakkan bahwa sampel bersifat amorf, namun pada pola difraktogram tersebut masih terlihat adanya dua peak (puncak) meskipun intensitas dan ketajaman puncaknya relatif rendah. Pada difraktogram a terdapat puncak pada sudut difraksi $2 \theta$ sebesar $13^{\circ}$ dan $27^{\circ}$ sedangkan difraktogram b puncak difraktogram pada sudut difraksi $2 \theta$ sebesar $11^{\circ}$ dan $23^{\circ}$. Adanya perlakuan kalsinasi pada sampel menyebabkan terjadinya pergeseran puncak difraktogram kearah jarak antar bidang yang lebih rendah dari $13^{\circ}$ ke $11^{\circ}$ dan dari $27^{\circ}$ ke $23^{\circ}$. Perlakuan tersebut menyebabkan terjadinya perubahan harga jarak antar bidang (d-spacing) pada sampel menjadi lebih besar dari $2^{\circ}$ ke $4^{\circ}$. Meningkatnya harga jarak antar bidang tersebut diduga porositas porous carbon yang dikalsinasi lebih tinggi dibanding porositas sampel tanpa kalsinasi. Untuk membuktikan dugaan tersebut dilakukan analisis dengan metoda adsorpsi gas (BET).

\section{Analisis Menggunakan Surface Area Analyzer}

Untuk mengetahui porositas dari porous carbon hasil sintetis, dilakukan karakterisasi menggunakan metode adsorpsi gas $\mathrm{N}_{2}$ berdasarkan pada teori BraunaneurEmmet-Teller (BET), hasil pengukuran tersebut disajikan pada Tabel 1.

Tabel 1. Distribusi ukuran pori Porous carbon

\begin{tabular}{cccc}
\hline Sampel & $\begin{array}{c}\text { Volum pori } \\
\text { total }\end{array}$ & $\begin{array}{c}\text { rata-rata } \\
\text { Jari-jari pori }\end{array}$ & $\begin{array}{c}\text { Luas permukaan } \\
\text { spesifik }\end{array}$ \\
\hline C1 & $70,75 \mathrm{cc} / \mathrm{g}$ & $1,40 \mathrm{~nm}$ & $155,90 \mathrm{sq} \mathrm{m} / \mathrm{g}$ \\
$\mathrm{C} 2$ & $140,27 \mathrm{cc} / \mathrm{g}$ & $1,40 \mathrm{~nm}$ & $308,65 \mathrm{sq} \mathrm{m} / \mathrm{g}$ \\
$\mathrm{C} 3$ & $88,66 \mathrm{cc} / \mathrm{g}$ & $1,47 \mathrm{~nm}$ & $194,74 \mathrm{sq} \mathrm{m} / \mathrm{g}$ \\
\hline
\end{tabular}

Dari tabel di atas dapat diamati perubahan pada pori-pori Porous carbon. Adanya pengaruh aktifasi yaitu kalsinasi pada suhu $600^{\circ} \mathrm{C}$ (sampel $\mathrm{C}_{2}$ ) terjadi penurunan berat dari 10 gram menjadi 3 gram. Hal ini dikarenakan ada sebagian karbon yang terbakar dan dilepaskan sebagai gas $\mathrm{CO}_{2}$. Adanya perubahan ukuran jari-jari pori rata-ratanya sebagai akibat adanya perlakuan aktifasi, akan tetapi pengaruhnya tidak signifikan. Ukuran pori hanya sekitar 0,02 $\mathrm{A}^{0}$ dari 1,4019 nm pada $\mathrm{C}_{1}$ menjadi $1,4039 \mathrm{~nm}$ pada $\mathrm{C}_{2}$, sedangkan pada volume pori mengalami peningkatan hampir dua kali lipatnya yaitu dari 70,7455 cc/g menjadi 140,2681 cc/g. Volume pori meningkat sebesar $98 \%$ sedangkan untuk luas permukaanya meningkat dari $155,90 \mathrm{sq} \mathrm{m} / \mathrm{g}$ menjadi 308,65 sq m/g atau luas permukaan meningkat sebesar $97 \%$. Berdasarkan hal tersebut dapat diduga bahwa jumlah pori meningkat oleh adanya perlakuan aktivasi, akibatnya porositas dari porous carbon yang dihasilkan juga ikut meningkat.

Penggunaan jenis asam yang berbeda pada proses karbonasi akan menghasilkan ukuran dan luas permukaan yang berbeda. Ukuran pori rata-rata pada $\mathrm{C}_{1}$ dengan asam sulfat sebesar 1,4019 nm menjadi 1,4736 nm pada $\mathrm{C}_{3}$ dengan asam nitrat. Ukuran volume pori $70,7455 \mathrm{cc} / \mathrm{g}$ menjadi $88,6567 \mathrm{cc} / \mathrm{g}$ atau volume pori meningkat sebesar $25 \%$ sedangkan luas permukaanya 
dari 155,90 sq m/g menjadi 194,74 sq m/g atau luas permukaannya meningkat sebesar $24 \%$.

Berdasarkan hasil tersebut dapat dinyatakan bahwa adanya perlakuan aktifasi dengan pemanasan atau kalsinasi meningkatkan porositas dari porous carbon yang dihasilkan, makin kuat sifat keasaman dari asam yang digunakan pada proses karbonasi maka porositas produk yang diperoleh semakin meningkat. Pada hasil analisis tersebut hasil terbaik diperoleh pada sampel $\mathrm{C}_{2}$.

\section{Pengujian porous carbon Sebagai adsorben pada} Pemucatan (Bleaching) Minyak goreng sisa pakai

Pengujian porous carbon hasil sintesis tersebut sebagai adsorben pada dasarnya bertujuan untuk menentukan kemampuan pemucatan porous carbon yang dihasilkan terhadap minyak goreng sisa pakai. Pemucatan minyak sisa pakai dilakukan dengan cara adsorpsi dengan adsorben porous carbon yang dihasilkan.

Proses bleaching dilakukan dengan menggunakan 10 mL minyak goreng sisa pakai dan $2 \% \mathrm{~b} / \mathrm{v}$ porous carbon dihasilkan. Dari hasil penelitian, didapatkan bahwa penggunaan porous carbon dengan variasi asam dan suhu yang ditambahkan menghasilkan tingkat pemucatan minyak goreng sisa pakai yang berlainan. Hasil pemucatan minyak goreng sisa pakai menggunakan Porous carbon, dengan pencucian HF $10 \%$ ditunjukkan oleh gambar 5. dan dengan pencucian $\mathrm{HF}$ 5\% ditunjukkan oleh gambar 6.

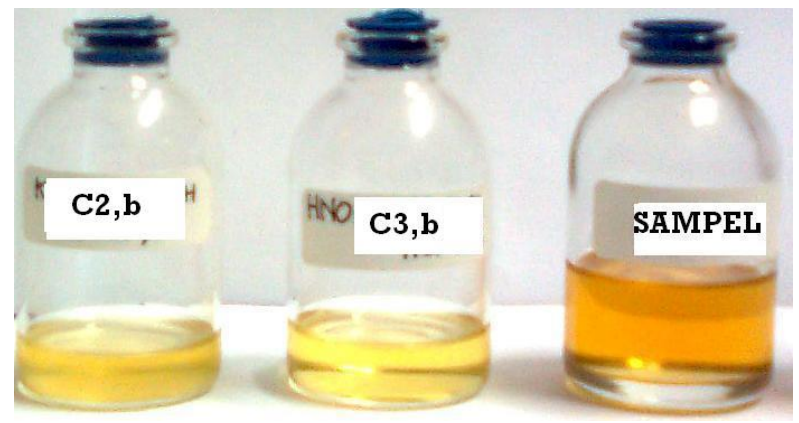

Gambar 5. Minyak goreng sisa pakai sesudah dan sebelum pemucatan dengan pencucian $\mathrm{HF} 10 \%$

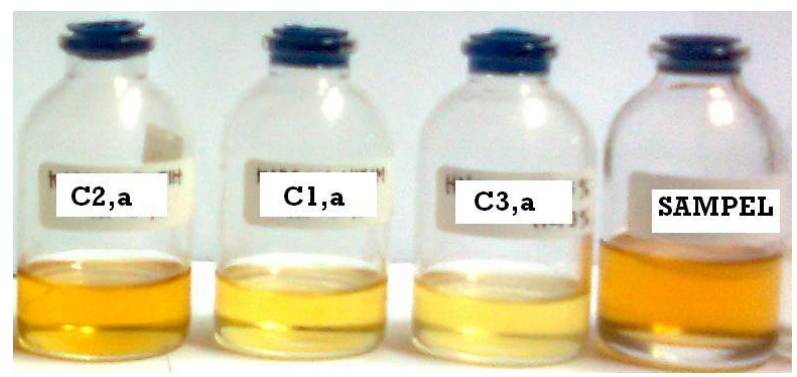

Gambar 6. Minyak goreng sisa pakai sesudah dan sebelum pemucatan dengan pencucian $\mathrm{HF} 5 \%$

Dari hasil bleaching sampel $\mathrm{C1}_{\mathrm{a}}$ dan sampel C2a terlihat ada perbedaan warna minyak setelah di adsorpsi, di mana hasil adsorpsi yang baik ditunjukan pada sampel $\mathrm{C}_{\mathrm{a}}$. Sampel C2a mengalami proses aktifasi pada suhu yang tinggi, sehingga dimungkinkan banyak karbon yang ikut terbakar dan dilepaskan sebagai gas $\mathrm{CO}_{2}$ serta carbon yang diaktifasi bersifat lebih porous hal ini sesuai dengan hasil dari BET. Selain itu akibat adanya aktifasi diduga banyak gugus aktif yang mengalami perubahan sehingga kemampuan adsorpsinya juga berubah. Sedangkan untuk sampel $\mathrm{C}_{\mathrm{a}}$ yang tanpa aktifasi masih banyak terdapat gugus aktif sehingga hasil adsorpsinya lebih baik dan minyak yang dihasilkan lebih jernih.

Pada sampel C2a dan sampel C2b, kemampuan adsorpsi yang baik ditunjukan pada sampel $\mathrm{C}_{2}$ b. Hal tersebut dimungkinkan karena silica banyak yang larut pada pencucian dengan $\mathrm{HF} 10 \%$ dibanding dengan $\mathrm{HF}$ yang $5 \%$, sampel $\mathrm{C} 2 \mathrm{~b}$ bersifat lebih porous dibanding sampel $\mathrm{C}_{\mathrm{a}}$ sehingga $\mathrm{C} 2 \mathrm{~b}$ kemampuan adsorpsinya lebih besar dibanding sampel C2a. Pada sampel $\mathrm{C}_{\mathrm{a}}$ dan sampel C3a, kemampuan adsorpsi yang baik ditunjukan pada sampel C3a. Hal tersebut disebabkan karena pengaruh jenis asam yang digunakan. Sampel C3a menggunakan asam nitrat yang mempunyai sifat oksidator yang lebih kuat bila dibandingkan dengan asam sulfat dan volume pori yang terbentuk akan lebih besar sehingga kemampuan mengadsorpsinya semakin besar juga. Sedangkan pada sampel C3a dan C3b warna yang dihasilkan dari proses adsorpsi sama, hal itu dimungkinkan adanya peningkatan konsentrasi $\mathrm{HF}$ untuk proses pencucian kurang efektif sehingga cukup dengan $\mathrm{HF}$ yang $5 \%$.

Berdasarkan hasil bleaching tersebut dapat dinyatakan bahwa porous carbon yang dibuat dengan menggunakan asam nitrat mempunyai kemampuan adsorpsi yang lebih tinggi dibanding dengan porous carbon yang lain.

\section{Kesimpulan}

Porous carbon dari sukrosa telah berhasil disintesis. Penggunaan asam nitrat sebagai reagen dapat meningkatkan luas permukaan dan volume produk berturut-turut sebesar $24 \%$ dan $25 \%$ relatif terhadap porous carbon yang dibuat dengan menggunakan asam sulfat. Adanya perlakuan kalsinasi porous carbon yang dibuat dengan menggunakan reagen asam sulfat dapat meningkatkan luas permukaan dan volume produk berturut-turut sebesar $97 \%$ dan $98 \%$. porous carbon yang diperoleh dapat digunakan sebagai adsorben minyak goreng sisa pakai. porous carbon yang dibuat dengan menggunakan asam nitrat mempunyai daya pemucatan terhadap minyak sisa pakai yang lebih tinggi dibanding dengan porous carbon yang dibuat dengan menggunakan asam sulfat.

\section{Daftar Pustaka}

[1] Sangho Bok, Arnold A Lubguban, Yuanfang Gao, Shantanu Bhattacharya, Venu Korampally, Maruf Hossain, Rajagopalan Thiruvengadathan, Kevin D Gillis, Shubhra Gangopadhyay, Electrochemical properties of carbon nanoparticles entrapped in a silica matrix, Journal of the Electrochemical Society, 155, 5, (2008) K91-K95 https://dx.doi.org/10.1149\%2F1.2868772

[2] M. M. Bruno, N. G. Cotella, M. C. Miras, T. Koch, S. Seidler, C. Barbero, Characterization of monolithic porous carbon prepared from 
resorcinol/formaldehyde gels with cationic surfactant, Colloids and Surfaces A: Physicochemical and Engineering Aspects, 358, 1, (2010) 13-20 https://doi.org/10.1016/j.colsurfa.2010.01.017

[3] G Svehla, Buku Teks Analisis Anorganik Kualitatif Vogel, Makro dan Semimikro, edisi ke-5, terjemahan L, Setiono dan AH Pudjaatmaka, PT. Kalman Media Pusaka, Jakarta, (1989) 270-275

[4] Robert M. Silverstein, Francis X. Webster, David J. Kiemle, David L. Bryce, Spectrometric Identification of Organic Compounds, 5 ed., John Wiley and Sons Inc., New York, 1991.

[5] RJ Fessenden, JS Fessenden, Kimia Organik, diterjemahkan oleh Pudjaatmaka, AH, jilid, 1, (1994) 209-210

[6] Hardjono Sastrohamidjojo, Spektroskopi, Yogyakarta: Liberty, (1991) 